\title{
Faktor-Faktor Yang Mempengaruhi Pertimbangan Auditor Dalam Mengevaluasi Bukti Audit Pada Kantor Akuntan Publik: Studi Empiris di Jawa Tengah dan DIY
}

\author{
Mulyadi $^{1)}$ \\ Yuniatin TDKW ${ }^{2)}$ \\ STIE Adi Unggul Bhirawa Surakarta \\ E-mail : mulyadi.ww@gmail.com
}

\begin{abstract}
Abstrak
Penelitian ini bertujuan untuk memberikan bukti empiris bahwa: Analisis Faktor-Faktor Yang Mempengaruhi Pertimbangan Auditor Dalam Mengevaluasi Bukti Audit Pada KAP Jawa Tengah dan DIY. Lokasi penelitian yang digunakan adalah Kantor Akuntan Publik di Jawa Tengah dan DIY. Populasi dalam penelitian ini adalah keseluruhan auditor yang bekerja di Kantor Akuntan Publik di Jawa Tengah dan dan DIY. Teknik dalam pengambilan sampel ialah Purposive Sampling. Sampel yang digunakan dalam penelitian ini sebesar 82 auditor. Instrumen penelitian diuji dengan menggunakan uji validitas dan uji realibilitas. Sedangkan untuk uji asumsi klasik digunakan uji normalitas, uji multikolonieritas, uji heteroskedastisitas dan uji autokorelasi. Data hasil penelitian ini dianalisis dengan teknik regresi linier berganda dan uji t. Hasil analisis hipotesis adalah Persuasi atas preferensi Klien, Tekanan Ketaatan, Pengalaman Audit dan Skeptismesecara individu berpengaruh positip dan signifikan terhadap Pertimbangan Auditor Dalam Mengevaluasi Bukti audit. Hasil uji $\mathrm{R}^{2}$ menunjukkan variabel Persuasi atas preferensi Klien, Tekanan Ketaatan, Pengalaman Audit, Skeptismemampu memberikan pengaruh sebesar 77,4\% terhadap Pertimbangan Auditor Dalam Mengevaluasi Bukti audit Audit, sedangkan sisanya sebesar $22,6 \%$ dipengaruhi faktor lain yang tidak diteliti, misalnya kompetensi, profesionalisme, dan kompleksitas tugas.
\end{abstract}

Kata Kunci :Pertimbangan Auditor Dalam Mengevaluasi Bukti audit, Persuasi atas preferensi Klien, Tekanan Ketaatan, Pengalaman Audit, Skeptisisme

\begin{abstract}
This study aims to provide empirical evidence that: Analysis of Factors Affecting Auditor Consideration in Evaluating Audit Evidence At KAP Central Java and DIY. The research location used is Public Accounting Firm in Central Java and DIY. The population in this study is the overall auditor who works in Public Accounting Firm in Central Java and and DIY. The technique in sampling is Purposive Sampling. The sample used in this study is 82 auditors. The research instrument was tested by using validity test and reliability test. As for the classical assumption test used normality test, multicolonierity test, heteroscedasticity test and autocorrelation test. The data of this research were analyzed by multiple linear regression and test. The result of hypothesis analysis is Persuasion on Client's preference, Pressure of Obedience, Audit Experience and Skepticism individually have a positive and significant impact on Auditor Consideration in Evaluating Audit evidence. The result of test of R2 shows variables of Persuasion on Client's preference, Pressure of Obedience, Audit Experience, Skepticism can give 77.4\% influence to Auditor's Consideration in Evaluating Audit Audit, while the rest of $22.6 \%$ is influenced by other factors not examined, for example competence, professionalism, and task complexity.
\end{abstract}

Keywords: Auditor's Consideration In Evaluating Audit Evidence, Persuasion on Client Preference, Pressure of Obedience, Audit 


\section{PENDAHULUAN}

Sekarang ini semakin banyak Kantor Akuntan Publik yang berdiri meningkatkan rasa persaingan untuk meningkatkan jumlah klien yang dimiliki. Di dalam menjalankan pekerjaannya, para auditor akan menjalankan tugas dan kewajibannya dengan sebaik-baiknya sehingga klien merasa puas akan kinerja mereka dan akan kembali menggunakan jasa mereka ketika mereka membutuhkannya. Kebanyakan klien yang datang akan berusaha menampilkan yang terbaik agar orang lain yang membaca dan mengerti akan bisnis berpikir bahwa perusahaan mereka adalah yang terbaik. Hal ini membuat auditor harus bekerja keras untuk memastikan kebenarannya dan setiap judgement yang dibuat oleh seorang auditor akan selalu mempengaruhi kinerja perusahaan klien kedepannya.

Auditor dalammelaksanakan pemeriksaan harus bersikap profesional pada tugasnya tersebut. Sebagai seorang profesional, auditor akan dituntut untuk berpegang pada tanggung jawab profesinya. Tanggung jawab profesi tidak berhenti sampai dia menyampaikan laporan kepada klien, tetapi dia akan bertanggung jawab terhadap isi pernyataan yang telah ditandatanganinya. Untuk itu auditor akan sangat berhati-hati sekali dalam melaksanakan tugas audit serta menetapkan keputusan yang akan diberikannya.

Beberapa kasus yang hampir serupa juga terjadi di Indonesia, diantaranya adalah dokumen dan laporan keuangan PT Bank Mandiri Tbk.yang dipalsupada tahun 2016 dan mark up atas laporan keuangan tahun 2014 oleh manajemen PT. Kimia Farma Tbk. yang terbukti melaporkan overstated laba bersih sebesar Rp 32 miliar. Kasus Kimia Farma sebenarnya kesalahan auditor adalah terlambat menyadari dan melaporkan adanya ketidakberesan yang dilakukan pihak manajemen perusahaan. Kesalahan tersebut diakibatkan karena auditor kurang berhati-hati dalam melakukan pengujian atas bukti audit yang seharusnya kompeten dan cukup.

Berkenaan dengan lingkup pengujian, penentuan ukuran sample dan item mana yang akan diuji, pertimbangan (judgement) auditor akan sangat mempengaruhi. Pertimbangan auditor dalam hal ini mencakup materialitas, risiko, biaya, manfaat, ukuran, dan karakteristik populasi.Karena itu apabila auditor tidak berhati-hati dalam menentukan pertimbangannya, maka kesalahan dalam pernyataan pendapat dapat saja terjadi.Banyak faktor yang dapat mempengaruhi pertimbangan \{judgement) auditor, diantaranya adalah preferensi klien dan pengalaman audit.Preferensi klien dalam konsep auditing terjadi apabila klien dengan jelas menyatakan suatu hasil tertentu atau perlakuan akuntansi tertentu yang diinginkan dan auditor berperilaku secara konsisten dengan keinginan klien itu (Haynes 1998).

Pertimbangan (judgement) auditor dapat menjadi bias terhadap perlakuan akuntansi yang dipreferensikan klien tersebut karena auditor dibayar oleh klien dan ingin memberikan kepuasan kepada kliennya untuk mempertahankan bisnisnya. Tetapi di lain pihak, auditor dihadapkan pada kemungkinan perkara hukum yang akan timbul di masa yang akan datang, kehilangan reputasi, dan sangsi dari organisasi profesi yang dapat menetralkan bias tersebut. Lagipula auditor harus mempertahankan objektivitas dan independensinya. Untuk mengetahui bagaimana pengaruh persuasi atas preferensi klien dan pengalaman audit baik secara simultan maupun parsial terhadap pertimbangan (judgement) auditor dalam mengevaluasi bukti audit, maka penulis tertarik untuk melakukan penelitian tentang pengaruh persuasi atas preferensi klien, pengalaman audit, tekanan ketaatan dan skeptitisme terhadap pertimbangan auditor dalam mengevaluasi bukti audit pada Kantor Akuntan Publik di Surakarta, Yogyakarta dan Semarang.

\section{TINJAUAN PUSTAKA}

\subsection{Pengertian Bukti Audit}

Mulyadi (2002 : 74) dalam Ricky Aditia (2012) mendefinisikan bukti audit sebagai : Segala informasi yang mendukung angka angka atau informasi lain yang disajikan dalam laporan keuangan, yang dapat digunakan oleh auditor sebagai dasar untuk menyatakan pendapatnya.

Arens, Elder dan Beasley (2008 : 225) mendefinisikan bukti audit "sebagai setiap informasi yang digunakan oleh auditor untuk menentukan apakah informasi yang diaudit telah dinyatakan sesuai dengan kriteria yang ditetapkan". Bukti audit didefinisikan sebagai setiap informasi yang digunakan oleh auditor untuk menentukan apakah informasi yang diaudit telah sesuai dengan criteria yang ditetapkan.

Berdasarkan beberapa penjelasan pengertian bukti audit diatas maka dapat ditarik kesimpulan, bukti audit adalah Segala informasi yang mendukung data yang disajikan dalam laporan keuangan, yang digunakan auditor sebagai dasar untuk menyatakan pendapatnya mengenai kewajaran laporan keuangan.Informasi tersebut terdiri dari Bukti yang berasal dari data akuntansi dan bersifat 
sebagai informasi pendukung lainnya.Bukti yang berasal dari data akuntansi dapat berupa jurnal, buku besar dan buku pembantu, pedoman akuntansi terkait, Informasi dan catatan memorandum (kertas kerja perhitunganperhitungan, rekonsiliasi). Sedangkan Bukti yang merupakan informasi pendukung lainnya dapat berupa inspeksi dan pemeriksaan fisik, Konfirmasi dan pernyataan tertulis, dokumendokumen (cek, faktur, perjanjian, kontrak, dll), Informasi dari wawancara, observasi seperti obeservasi pada sistem pengendalian internal perusahaan.

Preferensi Klien dalam Pertimbangan (Judgement) Auditor

Preferensi klien dalam konsep auditing terjadi apabila klien dengan jelas menyatakan suatu hasil tertentu atau perlakuan akuntansi tertentu yang diinginkan dan auditor berperilaku dengan cara konsisten dengan keinginan klien itu (Haynes 1998). Riset-riset keperilakuan dalam auditing menyatakan bahwa preferensi klien akanberdampakterhadap pertimbangan audit hanya bila ada sejumlah kondisikondisi tertentu terjadi dalam konteks audit itu. Bila auditor mendapat pernyataan eksplisit mengenai preferensi klien yang bertentangan dengan preferensi auditor atau standar akuntansi sehingga terdapat hubungan berlawanan yang terbentuk antara auditor dan klien, maka studistudi yang telah dilakukan melaporkan efek preferensi klien yang kecil atau tidak ada (Gramling 1999; Buchman et al. 1996).

Sedangkan bila hubungan berlawanan itu dikurangi dengan memasukkan skenario tidak adanya pedoman otoritatif dalam standar akuntansi (Trompeter 1994), maka hasil studi menunjukkan efek preferensi klien yang lebih kuat. Dengan demikian tingkat ambiguitas menentukan pengaruh preferensi klien terhadap pertimbangan audit (Tri 2005)

\subsection{Kredibilitas Klien yang Menyatakan Preferensi}

Menurut Hovland dan Weiss (1952) dalam Taylor et al. (2000), kredibilitasterdiri atas dua komponen, yaitu: keahlian (expertise) dan kelayakan untuk dipercaya\{trustworthiness) dari sumber yang menyampaikan suatu informasi. Indikator darikredibilitas sumber yang menyampaikan informasi selanjutnya dibagi menjadikredibilitas tinggi dan kredibilitas rendah.

Sumber yang memil iki kredibilitas tinggi akan lebih dapat meyakinkan daripadayang memiliki kredibilitas rendah. Semakin tinggi keahlian/ kompetensi suatusumber, semakin tinggi pula keyakinan terhadap sumber tersebut. Bagaimanapun,pengaruh ini diharapkan dibatasi oleh kondisi preferensi awal karena auditor akanlebih sensitif terhadap preferensi klien hanya jika preferensi diketahui sebelummengevaluasi bukti. Hasilnya, interaksi yang diprediksikan dalam reaksi auditorterhadap preferensi klien secara diferensial dipengaruhi oleh kredibilitas klien,tetapi hanya dalam kondisi preferensi awal.

\subsection{Pengalaman Audit}

Pengalaman merupakan proses pembelajaran dan pertambahan perkembangan potensi. Pengalaman sesorang dapat diartikan sebagai suatu proses yang dapat membawa seseorang kepada suatu pola tingkah laku yang lebih tinggi. Pengalaman audit adalah pengalaman yang dimiliki seorang auditor dalam melakukan pemeriksaan dari banyaknya penugasan berbeda yang pernah dilakukan dan juga lamanya auditor menjalankan profesinya serta dapat menambah pengetahuannya mengenai pendeteksian kekeliruan. Standar umum yang pertama menyebutkan "Pemeriksaan harus dilaksanakan oleh seseorang atau orang-orang yang telah menjalani pendidikan dan latihan teknis yang cukup dalam bidang pemeriksaan akuntan dan memiliki keahlian sebagai akuntan publik" (IAI 2001). Standar ini menegaskan bahwa betapapun kemampuan seseorang dalam bidang lain, termasuk bidang usaha dan bidang keuangan, ia tidak dapat memenuhi persyaratan-persyaratan yang dimaksud dalam standar auditing, apabila ia tidak memiliki pendidikan dan pengalaman yang memadai dalam bidang pemeriksaan akuntan.

Pengalaman Auditor adalah pengalaman dalam melakukan audit laporan keuangan baik dari segi waktu, jumlah penugasan maupun jenis-jenis perusahaan yang pernah ditangani (Asih 2006:26). Auditor yang berpengalaman akan membuat keputusan yang lebih baik dibanding dengan auditor yang belum berpengalaman (Herliansyah dan Meifida, 2006). Seorang auditor yang berpengalaman akan semakin peka dalam memahami setiap informasi yang relevan sehubungan dengan keputusan yang akan diambilnya. Karena ia memiliki lebih banyak hal yang tersimpan dalam ingatannya dan dapat mengembangkan suatu pemahaman yang baik mengenai peristiwa-peristiwa yang terjadi.

Menurut Abdolmohammadi dan Wright (1987) dalam Aris Eddy Sarwono (2006), pengalaman dari seorang auditor merupakan komponen yang penting karena pengalaman merupakan suatu faktor yang sangat vital yang mempengaruhi keputusan yang kompleks. Di bidang audit, pengalaman 
auditor merupakan faktor penting yang dibutuhkan dalam menyelesaikan pekerjaannya. Pengalaman adalah salah satu penentu utama yang mempengaruhi efisiensi kinerja dalam praktek profesional.

Semakin tinggi pengalaman auditor, maka semakin tinggi kualitas pengambilan keputusan audit.Pengalaman bagi para auditor merupakan unsur penting dalam menjalankan tugasnya.Auditor yang profesional harus mempunyai pengalaman yang cukup tentang tugas dan tanggungjawabnya.Pengalaman auditor dapat menentukan profesionalisme, kinerja komitmen terhadap organisasi, serta kualitas auditor melalui pengetahuan yang diperolehnya dari pengalaman melakukan audit. Susetyo (2009) membuktikan bahwa pengalaman kerja seorang auditor akan menentukan tingkat evaluasi yang dimilikinya.

\subsection{Pertimbangan Auditor}

Pertimbangan auditor (auditor

judgement) sangat tergantung dari persepsi mengenai suatu situasi.Judgement, yang merupakan dasar dari sikap profesional, adalah hasil dari beberapa faktor seperti pendidikan, budaya, dan sebagainya, tetapi yang paling signifikan dan tampak mengendalikan semua unsur seperti pengalaman adalah perasaan auditor dalam menghadapi situasi dengan mengingat keberhasilan dari situasi sebelumnya. Judgement adalah perilaku yang paling berpengaruh dalam mempersepsikan situasi, dimana faktor utama yang mempengaruhinya adalah materialitas dan apa yang kita yakini sebagai kebenaran (Siegel dan Marconi 1989).

\subsection{Tekanan Ketaatan}

Tekanan ketaatan adalah jenis tekanan pengaruh sosial yang dihasilkan ketika individu dengan perintah langsung dari perilaku individu lain. Teori ketaatan menyatakan bahwa individu yang memiliki kekuasaan merupakan suatu sumber yang dapat mempengaruhi perilaku orang dengan perintah yang diberikannya (Idris, 2012). Tekanan ketaatan ini timbul akibat adanya kesenjangan ekspektasi yang terjadi antara entitas yang diperiksa dengan auditor telah menimbulkan suatu konflik tersendiri bagi auditor. Dalam suatu audit umum, auditor dituntut untuk memberikan pendapat mengenai kewajaran laporan keuangan entitas untuk menghindari adanya pergantian auditor. Pemberian opini wajar tanpa pengecualian tanpa bukti-bukti audit yang memadai, dapat berubah dari masalah standar audit (khususnya masalah standar pelaporan) ke masalah kode etik (independensi dan benturan kepentingan).
Pemenuhan tuntutan entitas merupakan pelanggaran terhadap standar. Dan auditor yang tidak memenuhi tuntutan klien dianggap termotivasi untuk menerapkan standar audit (Theorodus 2007).

Tekanan ketaatan dihasilkan oleh individu yang memiliki kekuasaan dimana dalam hal ini, tekanan tersebut diartikan sebagai tekanan yang diterima KAP dari entitas yang diperiksa untuk melakukan tindakan yang menyimpang dari standar etika dan profesionalisme. Individu yang memiliki kekuasaan adalah sumber yang dapat mempengaruhi perilaku orang lain dengan perintah yang diberikannya (Jamilah et.al., 2007). Penyebabnya adalah keberadaan kekuasaan atau otoritas yang merupakan bentuk dari legitimate power. Tekanan ketaatan semakin rumit ketika auditor dihadapkan pada konflik karena auditor harus bersikap independen dalam memberikan pendapat mengenai kewajaran laporan keuangan, akan tetapi di sisi lain auditor juga harus dapat memenuhi tuntutan entitas yang diperiksa agar entitas tersebut puas dengan pekerjaannya. Tekanan ketaatan dapat menghasilkan variasi pada keputusan auditor dan memperbesar kemungkinan pelanggaran standar etika dan profesional (Jamilah et.al, 2007).

\subsection{Skeptisme Profesional}

Skeptisisme Profesional Skeptisisme profesional auditor adalah sikap yang mencakup pikiran yang selalu mempertanyakan dan melakukan evaluasi secara skeptis terhadap bukti audit.Auditor menggunakan pengetahuan, keterampilan, dan kemampuan yang dituntut oleh profesi akuntan publik untuk melaksanakan tugasnya dengan cermat dan seksama (Gusti dan Ali, 2008).Skeptisisme profesional yang dimaksud disini adalah sikap skeptis yang dimiliki seorang auditor yang selalu mempertanyakan dan meragukan bukti audit.Dapat diartikan bahwa skeptisisme profesional menjadi salah satu faktor dalam menentukan kemahiran profesional seorang auditor. Kemahiran profesional akan sangat memengaruhi ketepatan pemberian opini oleh seorang auditor. Dengan demikian dapat dikatakan bahwa semakin tinggi tingkat skeptisisime seorang auditor dalam melakukan audit, maka diduga akan berpengaruh pada ketepatan pemberian opini auditor tersebut (Noviyanti, 2008).

\section{HIPOTESIS}

3.1 Pengaruh Persuasi atas preferensi klien terhadap pertimbangan auditor dalam mengevaluasi bukti audit

Riset tentang preferensi klien beberapa diantaranya dilakukan oleh 
Gramling (1999), Buchman et al. (1996), dan Trompeter (1994).Hasil dari riset-riset tersebut beragam.Jika preferensi klien yang dinyatakan secara eksplisit bertentangan denganpreferensi auditor atau standar akuntansi, maka pengaruh preferensi klien dilaporkansangat kecil atau tidak ada.Sedangkan jika preferensi klien tidak berlawanan denganstandar akuntansi, maka hasil studi menunjukkan pengaruh preferensi klien yang lebih kuat.Preferensi klien secara persuasif ditekankan pada waktu penyampaian dankredibilitas sumber yang menyatakannya. Jika penyampaian preferensi dilakukansebelum auditor memeriksa bukti audit, maka diharapkan auditor akan lebihmemperhatikan preferensi tersebut. Dan jika kredibilitas sumber yang menyatakanpreferensi dapat dipercaya, maka diharapkan auditor juga akan lebih memperhatikan preferensi yang diminta. Enggar Diah Puspa Arum (2008) meneliti tentang Pengaruh persuasi atas preferensi klien terhadap pertimbangan auditor dalam mengevaluasi bukti audit. Hasilnya Persuasi atas preferensi klien berpengaruh positip terhadap pertimbangan auditor dalam mengevaluasi bukti audi

Hipotesis pertama yang diajukan adalah:

H1: Persuasi atas preferensi klien berpengaruh positif terhadap pertimbangan auditor dalam mengevaluasi bukti audit.

\section{Pengaruh Pengalaman audit terhadap pertimbangan auditor dalam mengevaluasi bukti audit}

Pengalaman mempunyai hubungan yang erat dengan keahlian auditor (Asih 2006). Semakin banyak pengalaman yang dimiliki oleh auditor akan semakin meningkatkan keahlian auditor dalam menjalankan tugasnya. Keahlian dan pengalaman dapat mempengaruhi kemampuan prediksi dan deteksi auditor terhadap kecurangan, sehingga dapat mempengaruhi Judgement yang diambil oleh auditor. Riset tentang pengalaman audit diantaranya dilakukan oleh Tri (2005), Shelton (1999), dan Haynes (1998). Hasil dari penelitian-penelitian tersebut umumnya mengindikasikan bahwa pengalaman berperan penting dalam membentuk judgement seorang auditor. Semakin berpengalaman seorang auditor, maka akan semakin mampu ia menganalisis pekerjaan yang lebih kompleks. Maria Magdalena Oerip Liana Sofiani dan Elisa Tjondro (2014) meneliti tentang Pengaruh pengalaman auditterhadap audit judgement. Hasilnya pengalaman auditberpengaruf positip fikanterhadap audit judgement
Hipotesis kedua yang diajukan adalah: $\mathrm{H} 2$ : Pengalaman audit berpengaruh positif terhadap pertimbangan auditor dalam mengevaluasi bukti audit.

5. Pengaruh Tekanan Ketaatan terhadap pertimbangan auditor dalam mengevaluasi bukti audit.

Menurut Hartanto (1999) dalam Siti Jamilah et.al.akuntan secara terus menerus berhadapan dengan dilema etika yang melibatkan pilihan antara nilai-nilai yang bertentangan. Dalam keadaan ini, klien bisa mempengaruhi proses pemeriksaan yang dilakukan oleh auditor. Klien bisa menekan auditor untuk mengambil tindakan yang melanggar standar pemeriksaan. Auditor secara umum dianggap termotivasi oleh etika profesi dan standar pemeriksaan, maka auditor akan berada dalam situasi konflik. Memenuhi tuntutan klien berarti melanggar standar.Namun dengan tidak memenuhi tuntutan klien, bisa mendapatkan sanksi oleh klien berupa kemungkinan penghentian penugasan.Karena pertimbangan profesional berlandaskan pada nilai dan keyakinan individu, kesadaran moral memainkan peran penting dalam pengambilan keputusan akhir. Penelitian sebelumnya menunjukkan bukti bahwa auditor yang mendapatkan perintah tidak tepat baik itu dari atasan ataupun dari klien cenderung akan berperilaku menyimpang dari standar profesional.Maria Magdalena Oerip Liana Sofiani dan Elisa Tjondro (2014) meneliti tentang Pengaruh tekanan ketaatanterhadap audit judgement. Hasilnya tekanan ketaatan berpengaruf positip terhadap audit judgement

H3: Tekanan Ketaatan berpengaruh positip terhadap pertimbangan auditor dalam mengevaluasi bukti audit.

6. Skeptisisme berpengaruh positip terhadap pertimbangan auditor dalam mengevaluasi bukti audit.

Skeptisisme Profesional Skeptisisme profesional auditor adalah sikap yang mencakup pikiran yang selalu mempertanyakan dan melakukan evaluasi secara skeptis terhadap bukti audit.Auditor menggunakan pengetahuan, keterampilan, dan kemampuan yang dituntut oleh profesi akuntan publik untuk melaksanakan tugasnya dengan cermat dan seksama (Gusti dan Ali, 2008).Skeptisisme profesional yang dimaksud disini adalah sikap skeptis yang dimiliki seorang auditor yang selalu mempertanyakan dan meragukan bukti audit.Dapat diartikan bahwa skeptisisme 
profesional menjadi salah satu faktor dalam menentukan kemahiran profesional seorang auditor. Kemahiran profesional akan sangat memengaruhi ketepatan pemberian opini oleh seorang auditor. Dengan demikian dapat dikatakan bahwa semakin tinggi tingkat skeptisisime seorang auditor dalam melakukan audit, maka diduga akan berpengaruh pada ketepatan pemberian pertimbangan auditor dalam mengevaluasi bukti tersebut (Noviyanti, 2008).Siti Amelia operasianti, Hendra Gunawan dan Mey Maemunah meneliti tentang(2016) meneliti tentang Pengaruh skeptisme terhadap Audit Judgment. Hasilnya skeptisme berpengaruh positip terhadap Audit Judgment

H4: Skeptitisme berpengaruh positip

terhadap pertimbangan auditor

dalammengevaluasi bukti audit.

\section{METODE}

Tujuan penelitian ini adalah untuk memberikan bukti empiris tentang pengaruhPersuasi atas Preferensi Klien, Pengalaman Audit, Tekanan Ketaatan dan Skeptisme Terhadap Pertimbangan Auditor dalam Mengevaluasi Bukti Audit Jumlah sampel dalam penelitian sebesar 85 responden dengan teknik purposive sampling. Teknik analisis dalam penelitian ini adalah regresi linier berganda dengan pengujian instrument : uji validitas, uji reliabilitas, uji asumsi klasik, analisis regresi linier berganda, uji t dan uji $\mathrm{R}^{2}$, sehingga dapat diperoleh gambaran perilaku 3 ) obyek penelitian.

\section{HASIL PENELITIAN}

Dari hasil analisis statistik diperoleh output penelitian, sebagai berikut :

\section{1) Uji Validitas}

Berdasarkan tabel hasil uji validitas yang disediakan, diketahui bahwa seluruh pernyataan yang digunakan dalam kuesioner dinyatakan valid, karena besarnya koefisien korelasi $\left(\mathrm{r}_{\text {item }}\right)$ untuk semua item pernyataan nilainya lebih besar dari $r_{\text {tabel }}(0,218)$ dengan tingkat signifikan 0,05 .

2) Uji Reliabilitas

Reliabilitas diukur dengan menggunakan metode cronbach alpha. Suatu variabel dikatakan reliabel jika nilai cronbach alpha> 0,60. Berdasarkan tabel hasil uji reliabilitas yang disediakan,4) diketahui bahwa seluruh variabel memiliki nilai cronbach alpha $>0,60$, sehingga dapat dikatakan kelima variabel tersebut dapat diandalkan atau reliabel. b. Uji Asumsi Klasik

1) Uji Normalitas

Tabel 1. Hasil Uji Normalitas

One-Sample Kolmogorov-Smirnov Test

\begin{tabular}{|c|c|c|c|}
\hline & & & $\begin{array}{l}\text { Unstandardiz } \\
\text { ed Residual }\end{array}$ \\
\hline \multirow[t]{2}{*}{$\begin{array}{l}\mathrm{N} \\
\text { Normal Parameters }\end{array}$} & $a, b$ & Mean &, $0000000^{82}$ \\
\hline & & Std. Deviation & 1,45855909 \\
\hline \multirow{3}{*}{$\begin{array}{l}\text { Most Extreme } \\
\text { Differences }\end{array}$} & & Absolute & ,101 \\
\hline & & Positive &, 101 \\
\hline & & Negative & -078 \\
\hline \multirow{2}{*}{\multicolumn{3}{|c|}{ Kolmogorov-Smirnov Z }} & 930 \\
\hline & \multicolumn{2}{|c|}{ Asymp. Sig. (2-tailed) } & 353 \\
\hline
\end{tabular}

b. Calculated from data.

Sumber : Data Primer yang diolah 2018

Dari hasil uji normalitas diatas, maka diperoleh nilai probabilitas value sebesar asymp.Sig.(2tailed) sebesar 0,353. Jadi, dapat dikatakan bahwa $\mathrm{p}$ value $>0,05$ sehingga data terdistribusi normal.

2) Uji Multikolonieritas Tabel 2. Hasil Uji Multikolonieritas

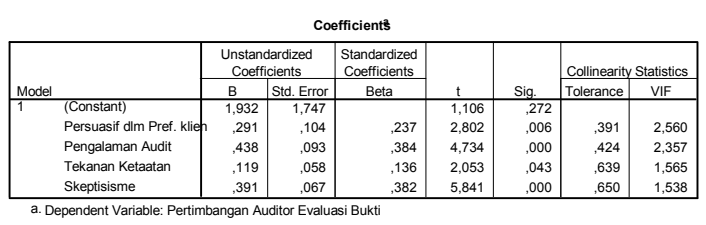

Sumber : Data primer yang diolah 2018

Hasil uji multikolonieritas diatas menunjukkan bahwa masing-masing variabel mempunyai nilai VIF (Variance Inflation Factor) $<10$ dan nilai tolerance $>0,10$. Hal ini menunjukkan bahwa tidak adanya masalah multikolonieritas dalam model regresi, sehingga memenuhi syarat analisis regresi.

3) Uji Heteroskedastisitas

Tabel 3. Hasil Uji Heteroskedastisitas

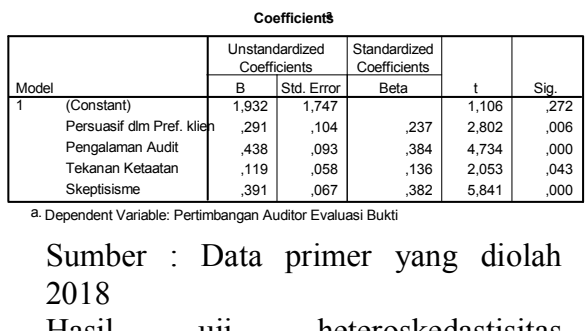

Hasil uji heteroskedastisitas menunjukkan nilai signifikan Pengalaman Kerja sebesar 0,706, Independensi sebesar 0,096, Akuntabilitas sebesar 0,117, dan Penerapan Teknologi Informasi sebesar 0,549 . Semua data tersebut nilainya lebih besar dari 0,05 . Hal ini berarti data tersebut lolos uji heteroskedastisitas atau tidak terjadi heteroskedastisitas antar residual.

4) Uji Autokorelasi

Tabel 4. Hasil Uji Autokorelasi 


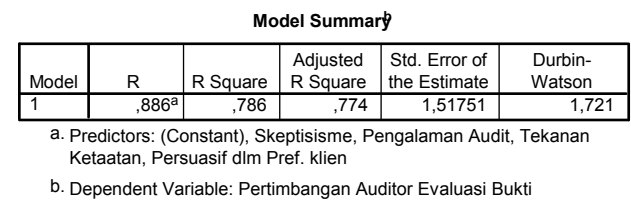

Sumber : Data primer yang diolah 2018

Hasil uji autokorelasi diatas dapat dilihat nilai Durbin Watson sebesar 1,742 akan dibandingkan dengan nilai tabel dengan derajat kepercayaan sebesar $5 \%$, jumlah sampel 85 dan jumlah variabel bebas 4, maka ditabel Durbin Watson akan didapat nilai du 1,7470 dan dl 1,5505. Nilai d 1,742, artinya hasil pengujian ini tidak terjadi masalah autokorelasi antar variabel, karena memenuhi persyaratan $\mathrm{dL}<\mathrm{d}<4-\mathrm{dU}$ dengan nilai $1,5505<1,742<4-1,7470$.

c. Uji Hipotesis

1) Uji Regresi Linier Berganda

Tabel 5. Hasil Uji Regresi Linier Berganda

\begin{tabular}{|c|c|c|c|c|c|c|}
\hline \multicolumn{7}{|c|}{ Coeff } \\
\hline \multirow[b]{2}{*}{ Model } & & \multicolumn{2}{|c|}{$\begin{array}{l}\text { Unstandardized } \\
\text { Coefficients }\end{array}$} & \multirow{2}{*}{$\begin{array}{c}\text { Standardized } \\
\text { Coefficients }\end{array}$} & \multirow[b]{2}{*}{$t$} & \multirow[b]{2}{*}{ Sig. } \\
\hline & & B & Std. Error & & & \\
\hline 1 & (Constant) & 1,932 & 1,747 & & 1,106 &, 272 \\
\hline & Persuasif dlm Pref. klie & ,291 & 104 & ,237 & 2,802 &, 006 \\
\hline & Pengalaman Audit & ,438 & 093 & 384 & 4,734 &, 000 \\
\hline & Tekanan Ketaatan & 119 & 058 & 136 & 2,053 & 043 \\
\hline & Skeptisisme & ,391 &, 067 &, 382 & 5,841 &, 000 \\
\hline
\end{tabular}

Sumber : Data primer yang diolah 2018

Dengan demikian diperoleh persamaan regresi linier berganda, yaitu :

$\mathrm{Y}=2,024+0,299\left(\mathrm{X}_{1}\right)+0,430\left(\mathrm{X}_{2}\right)+0,116\left(\mathrm{X}_{3}\right)+$

$$
0,392\left(\mathrm{X}_{4}\right)+\mathrm{e}
$$

Jadi semua variabel independen (Persuasi atas preferensi Klien, Tekanan Ketaatan, Pengalaman Audit, Skeptisme) berpengaruh positif terhadap variabel dependen (Pertimbangan Auditor Dalam Mengevaluasi Bukti Audit).

2) Uji t

Tabel 6. Hasil Uji t

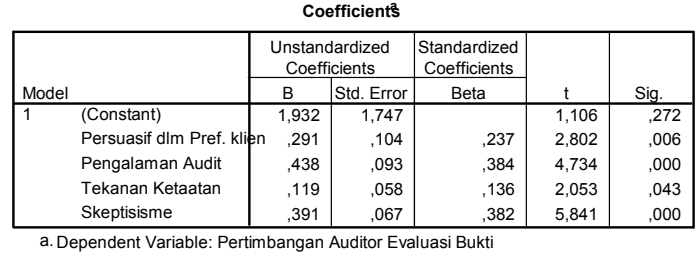

Sumber : Data Primer yang diolah 2018

Hasil analisis yang telah dilakukan diketahui besarnya nilai signifikan dari keseluruhan variabel $<0,05$. Kesimpulannya, Persuasi atas preferensi Klien, Tekanan Ketaatan, Pengalaman Audit, Skeptisme berpengaruh signifikan terhadap Pertimbangan Auditor Dalam Mengevaluasi Bukti Audit.

3) Uji Koefisien Determinasi

Table 7. Koefisien determinasi

\begin{tabular}{|l|c|r|r|r|c|}
\hline \multicolumn{7}{|c|}{ Model Summary } \\
\hline Model & R & R Scuare & $\begin{array}{c}\text { Adjusted } \\
\text { R Square }\end{array}$ & $\begin{array}{c}\text { Std. Error of } \\
\text { the Estimate }\end{array}$ & $\begin{array}{c}\text { Durbin- } \\
\text { Wa:son }\end{array}$ \\
\hline 1 &, $886^{\text {a }}$ &, 736 &, 774 & 1,51751 & 1,721 \\
\hline \multicolumn{3}{|c|}{ a Predictcrs: (Constant), Skeptisisme, Fengalaman Audi:, Tekanan } \\
Ketaatan, Persuasif dim Pref. klien \\
b. Dependent Variable: Pertimbangan Audtor Evaluasi Bukt
\end{tabular}

Sumber : Data primer yang diolah 2018

Nilai koefisien determinasi $\left(\mathrm{R}^{2}\right)$ sebesar 0,773 yang berarti pengaruh yang diberikan variabel Persuasi atas preferensi Klien, Tekanan Ketaatan, Pengalaman Audit, Skeptismeterhadap Pertimbangan Auditor Dalam Mengevaluasi Bukti Auditsebesar 77,4\% sedangkan 22,6\% dipengaruhi oleh variabel lain yang tidak termasuk dalam penelitian ini, misalnya profesionalisme, kompetensi, time budget pressure, audit fee, dan kompleksitas tugas.

\section{PENUTUP}

a. Kesimpulan

1) Persuasi atas preferensi Klien berpengaruh positif dan signifikan terhadap Pertimbangan Auditor Dalam Mengevaluasi Bukti Auditpada Kantor Akuntan Publik di Surakarta, Semarang dan DIY.

2) Tekanan Ketaatanberpengaruh positif dan signifikan terhadap Pertimbangan Auditor Dalam Mengevaluasi Bukti Audit pada Kantor Akuntan Publik di Surakarta, Semarang dan DIY.

3) Pengalaman Audit berpengaruh positif dan signifikan terhadap Pertimbangan Auditor Dalam Mengevaluasi Bukti Audit pada Kantor Akuntan Publik di Surakarta, Semarang dan DIY.

4) Skeptismeberpengaruh positif dan signifikan terhadap Kualitas Audit pada Kantor Akuntan Publik di Surakarta, Semarang dan DIY.

\section{b. Saran}

1) Untuk meningkatkan independensi auditor terhadap kualitas audit, maka dapat dilakukan dengan : a) pelaporan hasil audit bebas dari bahasa mengandung multitafsir, b) pelaporan bebas dari usaha pihak tertentu untuk mempengaruhi pertimbangan pemeriksaan terhadap isi laporan pemeriksaan, dan c) penyusunan program audit bebas dari usaha pihak 
lain untuk menentukan subyek pekerjaan pemeriksaan.

2) Untuk meningkatkan kemampuan penerapan teknologi informasi terhadap kualitas audit, maka dapat dilakukan dengan : a) produktivitas auditor dapat ditingkatkan dengan menggunakan teknologi informasi (komputer), dan b) kualitas output dari pekerjaan audit dapat ditingkatkan dengan teknologi informasi (komputer).

3) Peneliti selanjutnya diharapkan mampu mengembangkan variabel penelitian maupun indikator penelitian yang lain agar penelitian semakin lengkap dan lebih baik.

\section{DAFTAR PUSTAKA}

Ardini, Lilis. 2010. Pengaruh Kompetensi, Independensi, Akuntabilitas Dan Motivasi Terhadap Kualitas Audit. Majalah Ekonomi Tahun XX, (3), 6-7.

Ariviana, Bella. 2014. Pengaruh Akuntabilitas, Pengetahuan, Pengalaman dan Independensi Terhadap Kualitas Hasil Kerja Auditor(Studi Empiris Pada Kantor Akuntan Publik di Kota Semarang dan Surakarta). Simposium Nasional Akuntansi $\mathrm{X},(7), 5-11$.

Ayuningtyas, Harvita Yulian. 2012. Pengaruh Pengalaman Kerja, Independensi, Obyektifitas, Integritas, Dan Kompetensi Terhadap Kualitas Audit(Studi Kasus Pada Auditor Inspektorat Kota/Kabupaten di Jawa Tengah). Fakultas Ekonomika dan Bisnis Universitas Diponegoro Semarang.

Bustami, Afif. 2013. Pengaruh Independensi, Akuntabilitas Dan Profesionalisme Auditor Terhadap Kualitas Audit (Studi Empiris pada Kantor Akuntan Publik di DKI Jakarta). Fakultas Ekonomi dan Bisnis Universitas Islam Negeri Syarif Hidayatullah Jakarta.

Christiawan, Yulius Jogi. 2002. Kompetensi Dan Independensi Akuntan Publik : Refleksi Hasil Penelitian Empiris. Jurnal Akuntansi Dan Keuangan, 4, 79-92.

Febriyanti, Reni. 2014. Pengaruh Independensi, Pengalaman, Due Professional Care dan Akuntabilitas Terhadap Kualitas Audit (Studi Empiris Pada Kantor Akuntan Publik di Kota Padang dan Pekanbaru). Fakultas Ekonomi Universitas Negeri Padang. Journal of Chemical Information and Modeling.
Futri, Putu Septiani., \& Juliarsa, Gede. 2014. Pengaruh Independensi, Profesionalisme, Tingkat Pendidikan, Etika Profesi, Pengalaman Dan Kepuasan Kerja Auditor Terhadap Kualitas Audit Pada Kantor Akuntan Publik Di Bali, 41-58.

Ghozali, Imam. 2012. Aplikasi Analisis Multivariate dengan Program IBM SPSS 20.Semarang: Badan Penerbit - Universitas Diponegoro.

Harahap, Lukman. 2015. Pengaruh Kompetensi, Independensi, Objektivitas Dan Sensitivitas Etika Profesi Terhadap Kualitas Hasil Audit (Studi Kasus Pada Auditor BPKP Daerah Istimewa Yogyakarta).

Hidayat, M. Taufik. 2011. Pengaruh Faktor-Faktor Akuntabilitas Auditor Dan Profesionalisme Auditor Terhadap Kualitas Auditor (Studi Empiris Pada Kantor Akuntan Publik Di Semarang). Universitas Diponegoro. Semarang.

IAI. 2002. Standar Profesi Akuntan Publik. Jakarta. Salemba Empat.

Iskandar, Melody., \& Stefani Lily Indarto. 2015. Interaksi Independensi, Pengalaman, Pengetahuan, Due Professional Care, Akuntabilitas Dan Kepuasan Kerja Terhadap Kualitas Audit. Jurnal Ekonomi Dan Bisnis Universitas Katolik Soegijapranata. Vol. XVIII.

Jauhari, Dian Dwi. 2013. Pengaruh Independensi, Pengalaman dan Akuntabilitas terhadap Kualitas Audit (Studi Empiris pada Auditor Kantor Akuntan Publik (KAP) Wilayah Surakarta dan Semarang). Fakultas Ekonomi dan Bisnis Universitas Muhammadiyah Surakarta.

Kristiyanto, Agus. 2014. Analisis Pengaruh Kompetensi, Independensi, Dan Pemanfaatan Teknologi Informasi Terhadap Kualitas Hasil Pemeriksaan Pajak (Studi Empiris pada Pemeriksa KPP Madya di Jakarta). Vol. 5. Hal 1-13.

Kurnia, Winda, Khomsiyah, \& Sofie. 2014. Pengaruh Kompetensi, Independensi, Tekanan Waktu, dan Etika Auditor Terhadap KualitasAudit. E-Journal Akuntansi Fakultas Ekonomi Universitas Trisakti.

Mardisar, Diani., \& Sari, R. N. 2007. Jurnal Pengaruh Akuntabilitas dan Pengetahuan Terhadap Kualitas Hasil Kerja Auditor. SNA X UNHAS. Makasar.

Mulyadi. 2002. Auditing. Universitas Gajah Mada. Buku I Edisi 6. Jakarta : Salemba Empat. 
Nandari, Ade Wisteri Sawitri., \& Made. Yeni Latrini. 2015. Pengaruh Sikap Skeptis, Independensi, Penerapan Kode Etik, Dan Akuntabilitas Terhadap Kualitas Audit. EJournal Akuntansi Universitas Udayana. Vol. X.I. Hal 164-181.

Pahlevando, Rezha. 2013. Pengaruh Akuntabilitas Dan Kompetensi Auditor Terhadap Kualitas Audit (Studi Kasus Pada Kantor Akuntan Publik se-Provinsi Yogyakarta). Fakultas Ekonomi Dan Bisnis Jurusan Akuntansi Universitas Muhammadiyah Surakarta.

Pratiwi, Runny Chaerunnisa., \& Nuryantoro. 2016. Pengaruh Independensi, etika Profesi Dan Kepuasan Kerja Auditor Terhadap Kualitas Audit (Studi pada Kantor Akuntan Publik di Wilayah Bandung).

Purwanda, Eka., \& Emmatrya Azmi Harahap. 2015. Pengaruh Akuntabilitas Dan Kompetensi Terhadap Kualitas Audit (Survey Pada Kantor Akuntan Publik Di Bandung), XIX(3), 357-369.

Riespika, Shinta., \& Sri Supadmini. 2012. Pengaruh Penugasan Audit, Akuntabilitas dan Pemahaman Sistem Informasi Terhadap Kualitas Audit (Survey empiris pada Auditor yang Bekerja di Kantor Akuntan Publik Jakarta Timur). Universitas Gunadarma Jakarta.

Samsi, Nur, Akhmad Riduwan., \& Bambang Suryono. 2012. Pengaruh Pengalaman Kerja, Independensi, Dan Kompetensi Terhadap KualitasHasil Pemeriksaan Dengan Kepatuhan Etika Auditor Sebagai Variabel Pemoderasi. Jurnal Akuntansi \& Manajemen, 1(12), 1-18.

Sembiring, Andi Yahya, \& Rustiana. 2010. Pengaruh Pengalaman Dan Akuntabilitas Terhadap Kualitas Audit Internal Inspektorat Daerah Istimewa Yogyakarta.EJournal Fakultas Ekonomi Universitas ATMA Jaya Yogyakarta.

Shintya, Agneus., Nuryatno, Muhammad., \& Oktaviani, Ayu Aulia. 2016. Pengaruh Kompetensi, Independensi, Dan Tekanan Anggaran Waktu Terhadap Kualitas Audit. E-Journal Fakultas Ekonomi Dan Bisnis Universitas Trisakti Jakarta.

Syarifudin, Hidayat. Sedarmayanti. 2011. Metodelogi Penelitian. Bandung: CV.Mandar Maju.

SPKN (Standar Pemeriksaan Keuangan Negara). Peraturan BPK RI No. 01 Tahun 2017. Ditama Binbangkum BPK RI.
Sugiyono. 2010. Statistika Untuk Penelitian. Bandung : Alfabeta.

Sugiyono. 2014. Metode Penelitian Pendidikan Pendekatan Kuantitatif, Kualitatif Dan $R \& D$. Bandung : Alfabeta.

Sukriah, Ika., Akram, \& Biana Adha Inapty. 2009. Pengaruh Pengalaman Kerja, Independensi, Obyektifitas, Integritas dan Kompetensi Terhadap Kualitas Hasil Pemeriksaan.

Teddy, Jurnali. 2001. Pengaruh Faktor Kesesuaian Tugas Teknologi dan Pemanfaatan Teknologi Informasi Terhadap Kinerja Akuntan Publik. Simposium Nasional Akuntansi IV : 432-452.

Tuta, Ayu Andira. 2014. Pegaruh Kompetensi, Independensi, Profesionalisme, dan Sensitivitas Etika Profesi Audit Terhadap Kualitas Auditor. (Survey pada Kantor Akuntan Publik di Surakarta, Semarang dan $D I Y)$. Skripsi Sekolah Tinggi Ilmu Ekonomi Adhi Unggul Bhirawa. Surakarta.

Uma, Sekaran. 2006. Metodologi Penelitian untuk Bisnis. Edisi 4 Buku 1. Jakarta: Salemba Empat.

Uma, Sekaran. 2011. Metode Penelitian untuk Bisnis. Jakarta: Salemba Empat.

Wiratama, William Jefferson \& Ketut Budiartha. 2015. Pengaruh Independensi, Pengalaman Kerja, Due Professional Care dan Akuntabilitas Terhadap Kualitas Audit. EJournal Akuntansi Universitas Udayana. 